\title{
A pattern of adult involvement in highway acidentes
}

Paulina Bertól Bringmann ${ }^{1}$

Érika Cristina Ferreira ${ }^{1}$

Nevton Valdir Bringmann ${ }^{1}$

Sandra Maria Pelloso ${ }^{1}$

Maria Dalva de Barros Carvalho ${ }^{1}$

\begin{abstract}
This study aimed to identify the set of circumstances that contributed to the involvement of adults in traffic accidents. The study was of the cross-sectional type using secondary data. The patterns were identified through cluster analysis using a method called Hierarchical Ascendant Classification. Five classes were identified. Three classes involved males with minor injuries resulting from accidents between vehicles or vehicle-object, during the daytime and with dry road surface conditions. Two classes involved females, resulting in severe injuries, and were notable for occurring during the night and with a lower rate of use of seat belts. The findings of this study, especially in relation to the more serious accidents involving the female drivers, draw attention to this situation and point to a need for further studies involving these classes, which are increasingly common in traffic patterns.
\end{abstract}

Key words Traffic accidents, Adult, External causes, Highways, Cross-sectional studies

\footnotetext{
${ }^{1}$ Departamento de Medicina, Centro de Ciências da Saúde, Universidade Estadual de Maringá. Av. Colombo 5790, Jd. Universitário. 87020900 Maringá PR Brasil. paulinabertol@gmail.com
} 


\section{Introduction}

Traffic accidents, together with homicides and suicides, are included in the causes of morbidity and mortality of a violent nature. It is difficult to measure the significance of these deaths, but an idea can be obtained by comparing them with the total number of deaths in military operations: these latter deaths are substantially lower than any of the three categories mentioned above when taken individually ${ }^{1}$.

The importance of traffic accidents, from the perspective of public health, is that they are preventable and are more prevalent among younger people. More than half of the fatal victims are aged between 15 and 44 years, which is the most productive period of people's lives. Projections indicate that by the year 2020, the incidence of these deaths will show a decrease in high-income countries. On the other hand, they are projected to increase considerably in low and middle income countries, rising to sixth position in the list of the main causes of death on a worldwide basis².

Brazil is one of the ten countries with the highest rates of traffic accident mortality $y^{3}$. In the last three decades, traffic accidents have claimed more lives than homicides and suicides and the majority of diseases ${ }^{4}$. This cause of mortality can be linked to the chosen transport system model, which has given priority to roads and the use of private cars, without providing adequate infrastructure, and is often ill-prepared to deal with traffic regulation violations ${ }^{3}$.

An analysis of an eight-year period (19982005) showed that the National Traffic Department (DENATRAN)'s information system registered an increase in the number of accidents year on year. It should be noted that the data referred to accidents where there was at least one victim, and projected a relative increase of $46.1 \%$. As regards the types of accidents, a time series from 1999 to 2005 demonstrated that collisions were most prevalent (50\%); of these, more than half occurred during the day, and about $70 \%$ were in urban areas and, in $13 \%$ of cases, there was no information ${ }^{5}$.

In the period 1998-2008, data from the Mortality Information System (MIS), showed a disturbing increase in the number of deaths in car accidents, of the order of $23.9 \%$. While the deaths from people being run over declined, they more than doubled for car occupants $s^{5}$, with the State of Paraná being among the six states with the highest mortality rates ${ }^{6}$.
An analysis of the trends in traffic accident mortality over time identified a cluster of increased risk in an area consisting of a large number of municipalities in Paraná, Santa Catarina and some in São Paulo, which bordered with Paraná.

Studies of highway accidents are useful in order to understand the circumstances in which they occurred. However, it should be emphasized that on many occasions such occurrences, particularly those of a minor nature which did not involve death or hospitalization, were not registered in publicly accessible data banks such as DENATRAN, MIS and the Hospital Information System (HIS). Given the above situation, studies carried out using private databases are important for understanding the circumstances surrounding these events that, once identified, can be useful in establishing prevention measures.

The aim of this study was to identify the set of circumstances that, based on the similarity between the events, contributed to a pattern of involvement of adults in traffic accidents.

\section{Methodology}

The study was of the cross-sectional type using secondary data. Data was collected on the traffic accidents that occurred, during the year 2010, on a group of highways (known as Lot 2) that are part of the Paraná Integrated Highway Ring System. This lot has been administered by 'Concessionária Rodovias Integradas do Paraná S.A' (Viapar), since 1997, under the supervision of the State Department for Highways (DER). The state's highway network consists of highways managed by public institutions or by private companies through concessions (concessionaires). This lot under concession is composed of the highways denominated BR 158, 369 and 376, and PR 317 and 444. These highways cut across the State of Paraná in the North, Northwest and West. Their combined length is $547 \mathrm{~km}$, and is a mix of dual-lane $(127 \mathrm{~km})$ and single-lane (420 $\mathrm{km}$ ) highway. The daily traffic flow consisted of approximately 55 thousand vehicles, of which $74 \%$ were light vehicles (cars and vans), $20.5 \%$ trucks/trailers, $3 \%$ buses and $2.5 \%$ motorcycles.

Data was collected on all the traffic accidents that involved drivers of passenger vehicles and vans, aged between 20-39 years that occurred in a one-year period, based on the accident reports issued by the concessionaire's rescue teams when they attend victims. 
In this study, the term traffic accident was used to refer to accidents that occurred during transportation on public roads, involving only motor vehicles. These accidents are specified in the International classification of diseases (ICD), 10th revision, in the chapter on "External causes of morbidity and mortality", in the categories from V40 to V597.

The variables related to the driver for which data was collected were: sex; age, categorized into two groups according to the age groups used by the MIS, that is, 20-29 years and 30-39 years; severity of injury, categorized based on the assessment made by the pre-hospital rescue team that made the first contact, using the Glasgow Coma Scale and the Modified Trauma Scale for the condition of each victim: uninjured, mild injury, moderate injury, severe injury and death; other variables included the refusal of the driver to receive assistance, when he/her exercised this right, and the use of safety devices: seat belt. The variables related to the circumstances of the accident for which data was collected were: time of the year (season); day of the week; time of day, categorized into four periods: early morning (00:00-05:59), morning (06:00-11:59), afternoon (12:00-17:59) and evening (18: 00-23:59). In addition we collected data for the variables of the type of impact, classifying them as: vehicle-vehicle, vehicle-object, rollover and others, which included skidding, leaving the road and tipping over; highway surface conditions: either wet or dry; year of vehicle manufacture, categorized in the ranges: 1984 or earlier, 1985 - 1989, 1990 1994, 1995 - 1999 and 2000 or later; and type of highway; single or dual-lane.

For data analysis, the selected variables were in mutually exclusive categories. The coded values of these variables were analyzed simultaneously ( 1,251 cases, 42 categories of 11 variables), employing a classification method called Hierarchical Ascendant Classification (HAC) ${ }^{8}$. This form of classification is an analysis method for grouping and appropriate for the treatment of data that has been categorized. It splits the cases under study into a number of classes, so that each case belongs to one, and only one, class. The criterion used for the classification of cases (and also of classes), in ascending order, was its similarity, that is, its proximity, estimated by the chi-squared test.

After the system of classes had been structured four criteria were used to decide on the number of classes to be used. The intra-class variation indicated the degree of similarity among the events within the class. The smaller the value, the more similar were the events. The inter-class variation indicated the degree of difference between each class and the others. The goal was to minimize the intra-class variation and maximize the inter-class variance. The total variation of the data was equal to the sum of the intra and inter-class variations. The consistency in the interpretation of classes referred to the information contained in a class, related to the categories that made a more significant contribution to its formation ( $\mathrm{p}$ $<0.05$ ). If one or more classes was/were not very informative, it/they was/were moved up or down in the hierarchical classification.

Previous applications of this method in research on traffic injuries were found in studies on fatal traffic accidents ${ }^{9}$. The statistical analysis was carried out using the statistical software packages SAS 9.1 (Statistical Analysis System ${ }^{\circledR}$ ) and STATLab 30.32 (Logiciel d'Analyse Statistique of Données $\left.{ }^{\circledR}\right)$.

The development of the study followed the ethical guidelines laid out in Resolution No. $196 / 96^{10}$ issued by the National Council for Research Ethics (CONEP) and the project itself was approved by the Committee for Research Ethics of the State University of Maringá.

\section{Results}

A total of 1,251 accidents involving adult drivers was documented during the year 2010, on the stretch of highway that was researched. Five consistent and distinct classes were identified. The characteristics of these classes are described in Table 1.

Class 1: Accidents which occurred during the weekend on dual-lane highways involving males $(\mathrm{n}=331)$. These related, mostly, to males $(94 \%)$. Refused assistance (80.4\%). Dual-lane (58.6\%) and dry surface conditions (58.0\%). In the spring-time (37.4\%), involving skidding, leaving the highway and tipping over (36.3\%). In the afternoon (31.7\%), between Saturday (28.7\%) and Sunday (26.6\%). Drivers aged between 20 and 29 years $(51.1 \%)$.

Class 2: Accidents involving women who died at the site $(\mathrm{n}=9)$. Related exclusively to females, and resulted in death (100\%). Dry surface conditions (88.9\%) and dual-lane highways (66.7\%). Involving vehicle-to-vehicle (55.6\%). Not using seat belts $(55.6 \%)$. During the night $(44.4 \%)$, between Friday (33.3\%), Saturday (33.3\%) and Sunday $(22.2 \%)$. Drivers aged between 20 and 29 years $(66.7 \%)$. 
Tabela 1. Descrição das cinco classes resultantes da classificação hierárquica ascendente. Paraná, Brasil, 2010

\begin{tabular}{|c|c|c|c|c|c|}
\hline Variável & $\begin{array}{r}\text { Classe } 1 \\
(\mathrm{n}=331)\end{array}$ & $\begin{array}{r}\text { Classe } 2 \\
(n=9)\end{array}$ & $\begin{array}{r}\text { Classe } 3 \\
(\mathbf{n}=384)\end{array}$ & $\begin{array}{c}\text { Classe } 4 \\
(\mathrm{n}=340)\end{array}$ & $\begin{array}{r}\text { Classe } 5 \\
(n=187)\end{array}$ \\
\hline \multicolumn{6}{|l|}{ Sexo } \\
\hline Masculino & 94,0 & - & 87,8 & 84,7 & 30,0 \\
\hline Feminino & 6,0 & 100 & 12,2 & 15,3 & 70,0 \\
\hline \multicolumn{6}{|l|}{ Idade } \\
\hline 20 a 29 & 51,1 & 66,7 & 46,1 & 52,9 & 67,9 \\
\hline 30 a 39 & 48,9 & 33,3 & 53,9 & 47,1 & 32,1 \\
\hline \multicolumn{6}{|l|}{ Estação do ano } \\
\hline Primavera & 37,4 & - & 26,6 & 11,8 & 22,5 \\
\hline Verão & 24,8 & 33,3 & 17,7 & 21,8 & 29,9 \\
\hline Outono & 24,5 & 33,3 & 23,2 & 21,1 & 25,1 \\
\hline Inverno & 13,3 & 33,3 & 32,5 & 45,3 & 22,5 \\
\hline \multicolumn{6}{|l|}{ Dia da Semana } \\
\hline Segunda-Feira & 8,2 & - & 17,2 & 9,5 & 12,8 \\
\hline Terça-Feira & 9,4 & 11,1 & 14,1 & 11,4 & 8,6 \\
\hline Quarta-Feira & 10,9 & - & 12,2 & 13,2 & 17,1 \\
\hline Quinta-Feira & 2,6 & - & 21,9 & 13,8 & 11,8 \\
\hline Sexta-Feira & 13,6 & 33,3 & 15,9 & 10,9 & 11,8 \\
\hline Sábado & 28,7 & 33,3 & 10,2 & 20,6 & 18,7 \\
\hline Domingo & 26,6 & 22,2 & 8,5 & 20,6 & 19,2 \\
\hline \multicolumn{6}{|l|}{ Pista } \\
\hline Simples & 41,4 & 33,3 & 23,7 & 88,5 & 44,9 \\
\hline Dupla & 58,6 & 66,7 & 76,3 & 11,5 & 55,1 \\
\hline \multicolumn{6}{|l|}{ Período do dia } \\
\hline Manhã & 19,6 & - & 29,4 & 30,3 & 22,5 \\
\hline Tarde & 31,7 & 33,3 & 34,9 & 42,1 & 37,4 \\
\hline Noite & 22,7 & 44,4 & 32,6 & 20,8 & 22,5 \\
\hline Madrugada & 26,0 & 22,2 & 3,1 & 6,8 & 17,6 \\
\hline \multicolumn{6}{|l|}{ Ano de fabricação do Veículo } \\
\hline 1984 ou menos & 3,3 & - & 0,8 & 7,3 & 2,7 \\
\hline 1985 a 1989 & 1,5 & - & 0,5 & 7,3 & 5,8 \\
\hline 1990 a 1994 & 12,1 & - & 2,1 & 8,5 & 5,3 \\
\hline 1995 a 1999 & 24,8 & - & 8,3 & 15,9 & 16,6 \\
\hline 2000 ou mais & 58,3 & 55,6 & 88,3 & 60,6 & 44,4 \\
\hline Desconhecido & - & 44,4 & - & 0,3 & 25,1 \\
\hline \multicolumn{6}{|l|}{ Condições da Pista } \\
\hline Seca & 58,0 & 88,9 & 97,1 & 98,2 & 77,0 \\
\hline Molhada & 42,0 & 11,1 & 2,9 & 1,8 & 23,0 \\
\hline \multicolumn{6}{|l|}{ Tipo de impacto } \\
\hline Veículo-Veículo & 33,5 & 55,6 & 26,3 & 90,0 & 33,1 \\
\hline Veículo-Objeto & 30,2 & 11.1 & 66,7 & 7,1 & 9,1 \\
\hline Capotamento & - & - & - & 2,1 & 48,7 \\
\hline Outros & 36,3 & 33,3 & 7,0 & 0,8 & 9,1 \\
\hline \multicolumn{6}{|l|}{ Dispositivo de segurança } \\
\hline Cinto de Segurança & 86.4 & 44,4 & 87,8 & 90,0 & 78,1 \\
\hline Não usava cinto de Segurança & 13,6 & 55,6 & 12,2 & 10,0 & 21,9 \\
\hline \multicolumn{6}{|l|}{ Agravos } \\
\hline Recusa atendimento & 80,4 & - & 97,9 & 87,3 & 27,8 \\
\hline Sem agravos & 19,6 & - & 1,6 & 7,6 & 13,9 \\
\hline Leve & - & - & - & 1,2 & 33,2 \\
\hline Moderado & - & - & 0,5 & 2,1 & 15,5 \\
\hline Grave & - & - & - & 1,8 & 9,6 \\
\hline Óbito & - & 100 & - & - & - \\
\hline
\end{tabular}

As categorias das variáveis que significativamente contribuíram para a formação de cada classe estão marcadas em itálico. 
Class 3: Accidents with refusal of assistance involving an impact between vehicle-object $(\mathrm{n}=$ $384)$. Related to males $(87.8 \%)$, with refusal of assistance $(97.9 \%)$. Dry surface conditions $(97.1 \%)$ and dual-lane highways (76.3\%). Involving an impact between vehicle-object (66.7\%). Occurring in the afternoon $(34.9 \%)$, in winter $(32.5 \%)$, during the week, Thursday being the predominant day (32.5\%). Drivers aged between 30 and 39 years $(53.9 \%)$.

Class 4: Accidents involving vehicle-vehicle in single-lane highways, in winter $(\mathrm{n}=340)$. Related to males (84.7\%), involving an impact between two vehicles (90\%). Refused assistance $(87.3 \%)$. In dry surface conditions $(98.2 \%)$ and single-lane highways (88.5\%). In winter (45.3\%). In the afternoon $(42.1 \%)$, during the weekend, Saturday $(20.6 \%)$ and Sunday (20.6\%). Drivers aged between 20 and 29 years (52.9\%).

Class 5: Involving rollover accidents on dual-lane highways $(\mathrm{n}=187)$. Related to females (70.0\%). In dry surface conditions $(77.0 \%)$ and dual-lane highways $(55.1 \%)$, involving rollover $(66.7 \%)$, and resulting in minor injuries $(33.2 \%)$. In the afternoon $(37.4 \%)$, during the weekend, Saturday (18.7\%) and Sunday (19.2\%). Drivers aged between 20 and 29 years (67.9\%).

\section{Discussion}

Traffic accidents were examined from various perspectives, using source data that originated from police and/or hospital records. However, not all occurrences were captured by these systems. An overview of the traffic accidents that occurred on a given road stretch, based on information from a private data bank, originated at the site of the event, permitted the identification of the circumstances related to both the individual and the circumstances, which contributed to its occurrence.

\section{Accidents involving males resulting in minor injuries}

In these accidents the majority of the drivers was male (Classes 1, 3 and 4). They occurred in the afternoon during the weekend, when visibility conditions were generally good, on a dry highway surface, and involved a collision between two vehicles. This mirrored the profile of highway traffic accidents in Brazil. Research has been unanimous in identifying males, aged less than 40 years as the most common victims ${ }^{11}$. Further- more, $60 \%$ of accidents were in daylight, in good weather, on single-lane highways and during the weekend. What stood out was the kind of impact, a frontal collision ${ }^{12}$, similar to the findings of a study of a stretch of highway in the State of Mato Grosso, in which $55.8 \%$ of the accidents involved two vehicles, $56.3 \%$ occurred during the day, $63.3 \%$ with good weather conditions and $92.9 \%$ on a single-lane highway. This was the most prevalent in this location ${ }^{13}$.

However in this current study, the accidents were more prevalent on dual-lane highways, despite this being less frequent on the stretch of highway researched, representing only $25.6 \%$. This could be specifically associated with the adult driver, since the above-mentioned study did not define the age range of those involved in accidents.

In accidents, there are generally several factors that contribute, to a greater or lesser degree, to their occurrence. The human factor, highway conditions and type of vehicle are the most important contributors, with the human factor present in around 95\% of cases. Among the main sources of human error are: driving at a speed higher than permitted for the highway, not keeping a safe distance from the vehicle ahead, overtaking in a prohibited location and driving under the influence of alcohol or other drugs ${ }^{14}$. It should be noted that the testing for alcohol and other drugs of victims of traffic accidents is not routinely carried out in Brazil. However, it is commonly known, that younger people, possibly, are more likely to abuse the drinking of alcoholic beverages, thus leading to a higher risk of accidents ${ }^{15}$. Studies have identified that in fact younger people accept the risk of driving in such conditions ${ }^{16}$. Although a dual-lane highway represents a lower level of risk ${ }^{17}$, in the present study, the majority of accidents occurred on this type of highway. This could be a consequence of this profile of drivers that accept a greater exposure to risk.

In Classes 1 and 4 , the accidents were more prevalent during the weekend and involved the group of younger people, aged between 20 and 29 years. Younger people were underrepresented during the week and overrepresented at the weekend. Due to their driving being related to social activities they tended to gather in groups, and accepted the risk of driving in adverse conditions, such as during the weekend and after consumption of alcoholic drinks and/or other drugs ${ }^{16}$. Another factor that must be considered in the case of this group is the accumulated driv- 
ing experience, measured in terms of kilometers traveled. Younger people demonstrated a high risk driving pattern due to inexperience, a lower level of driving skill and less familiarity with the highway conditions ${ }^{18}$.

Class 3 represented the accidents that occurred during the week, revealing a possible highway usage profile for individuals between 29 and 39 years, which use it regularly for travel to/ from work or study activities, since the stretches of highway investigated connected small towns to large urban centers. The study investigated factors associated with this user profile and detected that accidents happened during the day, predominantly on Thursday ${ }^{19}$. Another finding revealed that the age group from 25 to 34 years was the most likely to be involved in accidents during commuting ${ }^{20}$. Although the occurrence of vehicle-object accidents has been linked to the daytime period, they occurred during the winter season, when the days were shorter and the level of light was lower. The level of light is an important factor in highway safety. A study comparing accidents occurring during the day and at night showed that the decrease in levels of illumination and image contrast caused images to be processed slowly by our visual capability, contributing to the severity of injuries ${ }^{21}$.

\section{Accidents involving females resulting in severe injuries}

In the accidents involving females, Classes 2 and 5 , the circumstances were commonly found to be associated with more severe accidents, such as during night driving and with a lower use of seat belts. Night driving for the group of younger people may not be so much a question of visibility, but more one of a consequence of how they drive ${ }^{22}$.

Females demonstrated a lower use of seat belts. Although the use of seat belts is one of the most common forms of protection, and despite being obligatory, it was observed that such use has not yet been fully adopted. A previous study found that a higher rate of accidents related to the non-usage of seat belts and, similarly to the present study, a trend towards a greater level of use by men ${ }^{22}$.

The greater involvement of females in serious accidents can be attributed to their lower participation as drivers in the highway context, leading to a lower level of familiarity with such condi- tions. In this present study, females accounted for only $14 \%$ of cases. Men tend to learn to drive at an early age, often before the age of 18 years, which is the minimum age stipulated under Brazilian law. Consequently they have greater experience in terms of accumulated driving experience ${ }^{23}$.

In the urban environment, females are more present. A study of females in the urban traffic profile found that a significant portion (65.0\%), mainly aged between 21 and 30 years, was predominantly involved in accidents during working days ${ }^{24}$.

In the case of Class 5, the majority of the accidents resulted in a rollover situation. Although in this kind of impact the vehicle model can be a factor, it occurred more frequently with younger drivers. This suggests there are levels of skills and behaviors that are inherent to certain groups of drivers, specifically in the case of younger people, that can lead to recklessness and poor judgment of traffic situation $\mathrm{s}^{25}$.

Some limitations of the present study should be taken into consideration. The classification of injuries, made at the crash site, may undergo a reclassification at a later time, such that an accident victim classified initially as in a serious condition could be reclassified as a death in a period of up to thirty days. Future studies, that could link up to other databases, would enable a more complete view of these accidents, not only in relation to the injuries, but also to the associated personal data, socio-economic data, health condition prior to the accident and traffic role.

Information on the type of vehicle, in relation to its model and year of manufacture, is important to enable the establishment of a prevention plan. Due to the study using a source of secondary data, it was not possible to obtain information on the year of manufacture of all of the vehicles involved, especially in those classes where females were most represented. Because of being a first time usage of this database, some variables were not collected, such as the type of vehicle involved and whether there was a police record of the accident. These factors should be addressed in the future.

The number of accidents in this study, which involved females, may have implications for the composition of the classes, which can be subject to fluctuations over time, due to the increased representation of females in society, and which fact also reflected in their greater participation in highway traffic. 


\section{Conclusion}

Despite the above mentioned limitations, this study provided evidence to expand the vision of the set of circumstances that contribute to adult involvement in accidents. Some of the circumstances contributing to accidents were already relatively well known, such as vehicle drivers being predominantly male, involved in vehicle-vehicle impacts, during the day, during the weekend and under dry surface conditions.

In the highway driving environment, females were less represented but were involved in more serious accidents in terms of injuries, reflecting a low perception of risk, in well-known risk situations, such as night driving and the non-use of seat belts.

The prevention of traffic accidents can be achieved through measures that minimize the circumstantial factors that contribute to their occurrence, related both to the context and the individuals involved. Among the recommended measures, some are already well known, such as the use of seat belts and the avoidance of driving in adverse conditions such as in low light conditions, at times of heavy traffic and during the weekend, the avoidance of distractions, keeping a safe distance between vehicles and looking out for possible objects on the highway surface.

In the majority of these accidents, there was a refusal to accept pre-hospital medical assistance, but without consequences in terms of injuries. Because of this high frequency, they should be estimated, since they generate personal and social costs, thereby deserving attention from the public health standpoint.

The scientific production in this area contributes to establishing strategies to improve the safety of highway users. The findings of this study, principally in relation to the more serious accidents involving the female drivers, drew attention to this situation and pointed to the need for further studies involving females, since their presence is increasingly common in traffic patterns.

\section{Collaborations}

PB Bringmann, EC Ferreira, MDB Carvalho, SM Pelloso e NV Bringmann participated equally in all stages of preparation of the article. 


\section{References}

1. Waiselfisz JJ. Mapa da Violência: Os Jovens da América Latina. São Paulo, Brasília: Instituto Sangari, Ministério da Justiça; 2008.

2. Toroyan T, Pedem M, editors. Youth end road safety. [serial on the Internet]. Geneva: World Health Organization; 2004. [cited 2011 Mar 10]. Available from: http:// whqlibdoc.who.int/publications/2007/9241595116 eng.pdf

3. Reichenheim ME, Souza ER, Moraes CL, Mello Jorge MHP, Silva CMFP, Souza Minayo MC. Violence and injuries in Brazil: the effect, progress made, and challenges ahead. Lancet 2011; 377(9781):1962-1975.

4. Minayo MCS. Morre menos quem morre no trânsito? Cien Saude Colet 2012; 17(9):2237-2238.

5. Mello Jorge MHPD, Koizumi MS. Acidentes de trânsito no Brasil: um atlas de sua distribuição. São Paulo (BR): Associação Brasileira de Medicina de Tráfego [serial on the Internet]. 2007. [cited 2011 Sep 10]. Available from: http://arquivos.abramet.com.br/downloads/atlas.zip

6. Morais Neto OLM, Montenegro MMS, Monteiro RA, Siqueira Júnior JB, Silva MMA, Lima CM, Miranda LOM, Malta DC, Silva Junior JB. Mortalidade por acidentes no Brasil na última década: tendência e aglomerados de risco. Cien Saude Colet 2012; 17(9):2223-2236.

7. World Health Organization (WHO). International statistical classification of diseases and health related problems. Geneva: WHO; 2004. [serial on the Internet]. [cited 2011 Sep 10]. Available from: http://apps.who. int/classifications/icd10/browse/2010/en

8. Hair JF, Anderson RE, Tathan RL, Black W. Análise multivariada de dados. $5^{\text {a }}$ ed. Porto Alegre: Bookman; 2006.

9. Skyving M, Berg H, Laflamme L. A pattern analysis of traffic crashes fatal to older drivers. Accid Anal Prev 2009; 41(Supl. 2):253-258.

10. Brasil. Ministério da Saúde (MS). Conselho Nacional de Saúde. Resolução nº 196 de 10 de outubro de 1996. Diretrizes e Normas Regulamentadoras de Pesquisas Envolvendo Seres Humanos. Diário Oficial da União 1996; 16 out.

11. Calil AM, Sallum EA, Domingues CA, Nogueira LS. Mapeamento das lesões em vítimas de acidentes de trânsito: revisão sistemática da literatura. Rev Lat Am Enfermagem [serial on the Internet]. $2009 \mathrm{Fev}$ [cited 2012 Nov 20];17(1):[about 5 p.]. Available from: http:// www.scielo.br/scielo.php?script=sci_arttext\&pid=S0 104-11692009000100019\&lng=pt.

12. Brasil. Ministério do Planejamento, Orçamento e Gestão, Instituto de Pesquisa Econômica Aplicada (IPEA), Ministério das Cidades, Departamento Nacional de Trânsito (Denatran). Impactos sociais e econômicos dos acidentes de trânsito em rodovias brasileiras - Relatório Executivo. Brasília (BR): IPEA/DENATRAN/ANTP [serial on the Internet]. 2006. [cited em 2011 set 10]. Available from: http://www.denatran.gov.br/publicacoes/ download/custos_acidentes_transito.pdf

13. Almeida LVC, Pignatti MG, Espinosa MM. Principais fatores associados à ocorrência de acidentes de trânsito na BR 163, Mato Grosso, Brasil, 2004. Cad Saude Publica 2009; 25(2):303-312.
14. Sabey B. Engineering safety on the road. Inj Prev 1995; 1(3):182-186.

15. Abreu AMM, Lima JMB, Matos LN, Pillon SC. Uso de álcool em vítimas de acidentes de trânsito: estudo do nível de alcoolemia. Rev Lat Am Enfermagem [serial on the Internet]. 2010 Jun [cited 2012 Nov 20]; 18(Spe.):[about 7 p.]. Available from: http://www. scielo.br/scielo.php?script=sci_arttext\&pid $=$ S0104 $11692010000700005 \& \operatorname{lng}=\mathrm{pt}$.

16. McGwin G, Brown DB. Characteristics of traffic crashes among young, middle-aged, and older drivers. Accid Anal Prev 1999; 31(3):181-198.

17. Staplin L, Lococo K, Byington S. Older Driver Highway Design Handbook. McLean (VA): Federal Highway Administration (US) Report n. FHWA-RD-01-103 [serial on the Internet] 2011 May. [cited 2011 Sept 10]. Available from: http://www.fhwa.dot.gov/publications/ research/safety/humanfac/01103/

18. Lardelli-Claret P, Luna-del-Castillo JD, Jiménez-Mejías E, Pulido-Manzanero J, Barrio-Anta G, García-Martín M, Jiménes-Moleón JJ. Comparison of two methods to assess the effect of age and sex on the risk of car crashes. Accid Anal Prev 2011; 43(4):1555-1561.

19. Kolcic I, Jovic AV, Rodin U, Bilos IB, Antoljak N, Polasek O. Commuting road traffic accidents in Croatia [abstract]. Inj Prev. Safety 2010; 16(1):A215-A216.

20. Boufous $S$, Williamson A. Work-related traffic crashes: a record linkage study. Accid Anal Prev 2006; 38(1):1421.

21. Braver ER, Trempel RE. Are older drivers actually at higher risk of involvement in collisions resulting in deaths or non-fatal injuries among their passengers and other road users? Inj Prev 2004; 10(1):27-32.

22. Mohammadi G. The pattern of fatalities by age, seat belt usage and time of day on road accidents. Int $J$ Inj Contr Saf Promot 2009; 16(1):27-33.

23. Andrade SM, Soares DA, Braga GP, Moreira JH, Botelho FMN. Comportamentos de risco para acidentes de trânsito: um inquérito entre estudantes de medicina na região sul do Brasil. Rev Assoc Med Bras 2003; 49(4):439-444.

24. Davantel PB, Pelloso SM, Carvalho MDB, Oliveira NLB. Women and traffic accidents: characterization of occurrences in Maringá, Paraná. Rev Bras Epidemiol 2009; 12(3):355-367.

25. Richardson J, Kim K, Li L, Nitz L. Patterns of Motor Vehicle Crash Involvement by Driver Age and Sex in Hawaii. J Safety Res 1996; 27(2):117-125.

Article submitted 14/09/2013

Approved 09/10/2013

Final version submitted 13/10/2013 